\title{
8 高分子材料による腐食防止*
}

\author{
奥田聡** \\ Managing Corrosion Problems with Plastics \\ by
}

\author{
Satoshi OKudA
}

(Department of Chemical Engineering, Doshisha University, Kyoto)

\section{$8 \cdot 1$ ま えがき}

高分子材料は金属材料に比べて種々の優れた特徴を もっている，たと党ば軽量で, 比強度が大きいこと, 外観が美しく塗装の必要がないことのほかに, 種々の 物理的，機械的性質の上での特徵を有する.とくに耐 食性についてはいわゆる耐食プラスチックスといわれ る次項に説明する各樹脂は金属にない優れた耐食性を 有し，これらの材料を金属材料と併行して使い分けて いくことは防食設計の要点であるといえる. 以下に耐 食プラスチックスの種類と適用範囲, 使用上の問題点 について述べる.

\section{$8 \cdot 2$ 耐食熱可塑性樹脂}

\section{$8 \cdot 2 \cdot 1$ ポリ塩化ビニル $(\mathrm{PVC})$}

PVC は最もポピュラーな樹脂であるが, 酸, アル カリによく耐觉，熱可塑性樹脂のなかでは比較的大き い強度と形状剛性を有することからまた最も経済的 でわが国の国状にもよく適用した樹脂であることか ら耐食樹脂として最も重要な材料である.

PVC には一般用のほかに耐衝撃用もあるが，一般 用 PVC はー $20^{\circ} \mathrm{C}$ 以下の低温ではもろくなって，ぜい 性破壞の危険性があること, $65^{\circ} \mathrm{C}$ 以上の高温では軟化 して使用に耐光ない，といら点がある.

耐熱 PVC は腐食性環境に使用した場合, 一般用 PVC 飞比べてその耐用温度は約 $20{ }^{\circ} \mathrm{C}$ 上昇する。 また その耐用温度は $100{ }^{\circ} \mathrm{C}$ である。

PVC 特よび耐熱 PVCがとくに優れている点は塩 素, 塩酸, 塩化物に対して強いことで, これらの環境 に耐壳らる金属材料としては八ステロイやチタンのよ らな高級耐食合金に限られるのに対して，PVC は前 記のよらな温度制度があるにしてる，これらの困難な 腐食性環境に大変適した材料であるといえる。

* 原稿受理 昭和53年 2 月 1 日

** 正蔭 員 同志社大学工学部 京都市上京区烏丸今出川
$8 \cdot 2 \cdot 2$ ポリプロピレン $(\mathrm{PP})$, ポリエチレン $(\mathrm{PE})$

硬質 PVC と泳湾同程度の耐薬品性を有し, 使用可 能な温度範囲がさらに広い樹脂にポリプロピレンがあ る. 同じポリオレフィン系の樹脂としてポリエチレン があるが，PE は腐食性環境で使用した場合，環境応 力割れを起しやすい欠点をるっている。一般に PP は PE よりも環境応力割れを起しにくい。

また $\mathrm{PE}$ あるいはPPが軽量であり，さらに耐食性 を有するといら二つの特徵により, 表面積の大きい種 々の形状の充てん塔の充てん物として使用されている.

\section{$8 \cdot 2 \cdot 3$ フッ素系樹脂}

フッ素樹脂は酸, アルカリのみならず有機溶剤にも 耐光，耐薬品性に関しては万能な材料である.しかし 加工には難点があり, また設計, 使用にあたっては他 の熱可塑性樹脂に比べて多くの注意が必要である. た とえば一般にこの樹脂は多孔性であり, 環境剤の透過 性も比較的大きい。

環境応力割れについてはフッ化ビニリデンを除いて 他のフッ素樹脂には起らないといわれている。つぎに フッ化炭素系樹脂のポピュラーな 7 種類について述べ る.

（1）四フッ化エチレン樹脂 (TFE または PTFE) フッ素樹脂の原形で, エチレンの四個の水素が全部フ ッ素に換っている. 加工が難しいが，高温下の種々の 侵食的ふ儿团気侸耐兄らる。耐用温度は $290^{\circ} \mathrm{C}$ である.

（2）フッ化エチレンプロピレン樹脂(FEP) 四フ ッ化ェチレンと六フッ化プロピレンの共重合物で, こ の樹脂は他のフッ素系樹脂と異り, 結晶化を起しにく 性質を有するので比較的柔軟性があり, 普通の射出, 押出成形，ヒートシールが可能であるなど加工性がよ い. 非粘着性, 低摩擦性なども PTFE とほとんど同

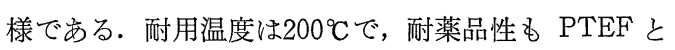
ほぼ同等である. 
（3） 三フッ化塩化エチレン樹脂 (CTFE) 而用温

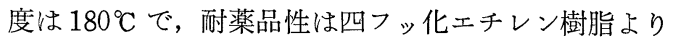
幾分劣るが，加工性は比較的よく，ライニング材， $\mathrm{O}$ ーリング材，ガスケットなどとして用いられる.

（4）フッ化ビニリデン樹脂 (ニフッ化樹脂, PVdF) 加工性がこの樹脂の出現により一新された。すなわち $\mathrm{PE}$ なみの加工性を有し，ディスパージョンライニン グのみならず粉体のままでライニングや成形が可能で, ヒートシールが容易にできる.

耐薬品性は PVC よりかなり優れて拈り, 大抵の酸, アルカリ, 炭化水素, カルボン酸, アルュール, 塩素 含有化合物に対して強い抵抗性を示す。また酸化剂, 八ロゲンガスのような腐食性ガスに対して侵されない。 また耐候性，耐摩耗性に優れている。

（5）フッ化ビニリデンと六フッ化プロピレンの共 重合物 この樹脂も顕著な化学抵抗性を示し, とくに 塩素, 臭素, ベンゼン, トルェン, 四塩化炭素, トリ クロルエチレン, $70 \%$ までの硝酸, 発煙硫酸, 溶融塩, 石油に対して強い抵抗性を有する。耐用温度は $150^{\circ} \mathrm{C}$ である.

（6）過フッ化アルコキシ樹脂（PFA）およびエチ レン-三フッ化塩化エチレン共重合物(ECTFE) この 二つの樹脂はそれぞれ $200^{\circ} \mathrm{C}$ 㧊よび $175^{\circ} \mathrm{C}$ の耐用温度 をもつ新しいフッ素系の樹脂である. 耐薬品性と加工 性㳸れている.

\section{$8 \cdot 2 \cdot 4$ 塩化ポリエーテル}

この樹脂は化学装置にコーティング，ライニングあ るいは樹脂単体として連続 $120^{\circ} \mathrm{C}$ までの温度に使用で きる.酸，アルカリによく耐光，とくに耐硫酸に優れ るが，溶剤系統にはよくない。

\section{$8 \cdot 2 \cdot 5$ ポリアミド}

ポリアミドは機械的性質の優れた樹脂で，耐用温度 は $100{ }^{\circ} \mathrm{C}$ と考光なければならない。吸水性が大きく， とくに酸によって加水分解し，耐薬品性はよくない． しかしナイロン11，12，13はナイロン6あるいはナイ ロン 6-6 に比べて吸水率が $1 / 10$ 以下であり, 耐食樹 脂としても期待できる.

以上の主な耐食熱可塑性樹脂について述べたが，図 $8 \cdot 1$ 飞その他の樹脂も含めて 熱可塑性樹脂の大要を 示す.

\section{$8 \cdot 3$ 耐食熱硬化性樹脂および耐食複合材料用樹脂}

\section{$8 \cdot 3 \cdot 1$ 不飽和ポリエステル}

一般用の FRP（強度プラスチック，Fiber Reinforced Plastics）に対して，とくに耐食性樹脂をマトリ ックス使用し，耐食目的に用いられる FRP を耐食 FRP という．耐食 FRP のマトリックスとして用い られる樹脂には表 8 ・I に示すように, イソフタール 酸系, ビスフェノール系, ヘット酸系があり, 一般用

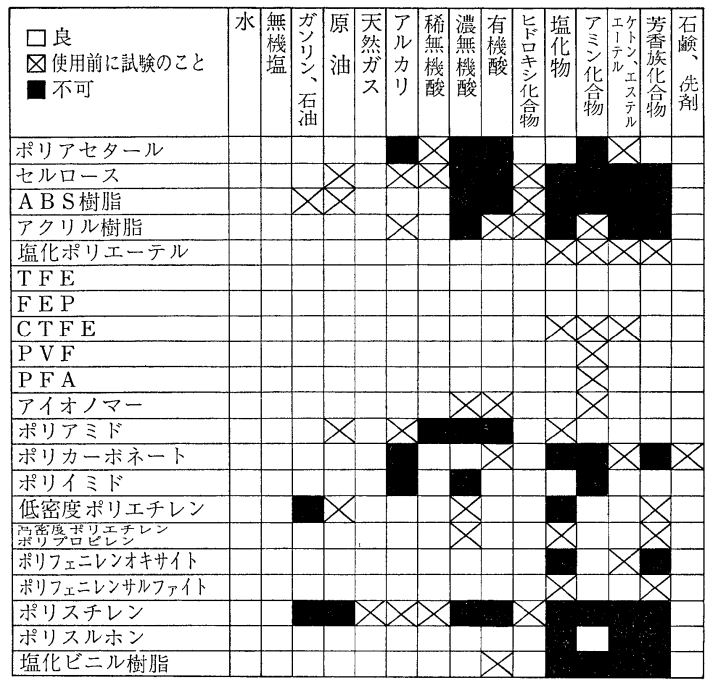

図 $8 \cdot 1$ 熱可塑性樹脂の耐薬品性

FRP として用いられる樹脂のオルソフタール酸系に 対比される. 一般に樹脂中のエステル基の含有率が高 ければ加水分解を起しやすくなり，耐食性は悪くなる が，オルソ系からイソ系，ビスフェノール系と進むに 従ってェステル基が少くなり，耐食性が增加すること がわかるまた前二者が主鎖中にベンゼン骨格を含ん でいるのに対して，ビスフェノール系ではビスフェノ 一ル骨格を主鎖の中にもっている：ビスフェノール骨 格は分子量も大きいためにそれだけェステル基濃度も 小さくなり，耐アルカリ性，耐酸性がよくなる.

$8 \cdot 3 \cdot 2$ エポキシ樹脂およびビニルエステル樹脂 一般用のエポキシ樹脂はビスフェノールAとェピク ロルヒドリンの反応生成物である.エポキシ樹脂は単 独で使用されることなく，その強度特性を出させるた めにはアミンやホルムアルデヒドのような硬化剂によ って架橋させられる.硬化剤の選択は重要である、エ ポキシ樹脂はビスフェノール骨格のみで，エステル基 をもたないので，耐薬品性に優れていることが期待で きる．しかし，常温硬化型になると硬化剤はアミン系 になるが,アミン自体アルカリ性であるので, 樹脂化合 物の耐アルカリ性は優れているが，耐酸性はよくない．

ビスフェノール A/エピクロルヒドリンーエポキシ樹 脂にメタアクリル酸を反応させて，その末端にメタク リル酸を付加したのがビスフェノール形ビニルエステ ルである、またフフェノール・ノボラック・エポキシ をべースにしたものがノボラック形ビニルエステルで ある.ビスフェノール系ポリエステル拉よびビニルェ ステル樹脂をマトリックスとする耐食 FRP 峙酸, ア ルカリの相当広い範囲にわたっての適応性があり, こ の点，金属でいえばハステロイ（高 $\mathrm{Ni}$ 合金）なみの 耐食性を有するといわれている，したがって化学装置 
表 8・I＼cjkstart不飽和ポリェステルの種類

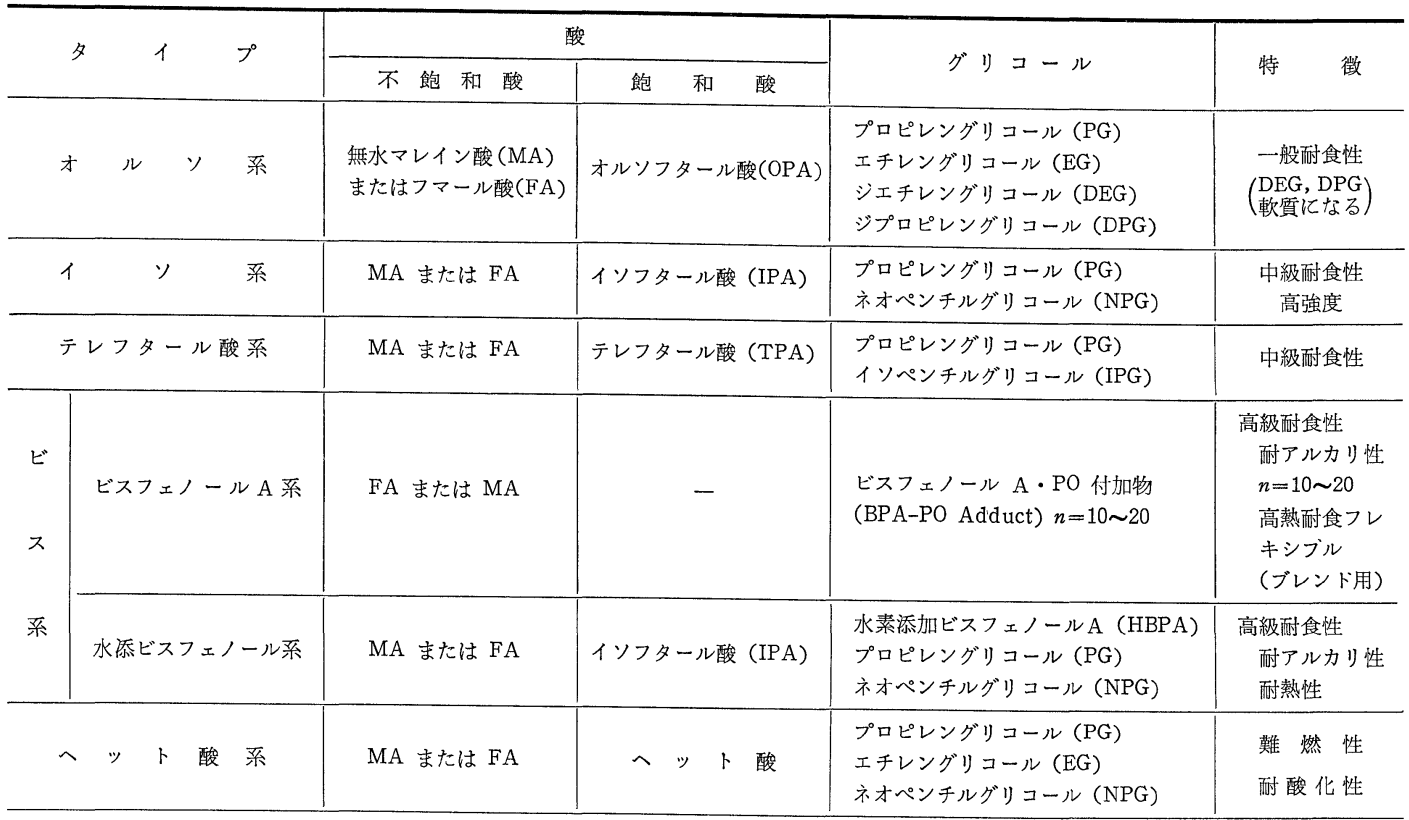

表 $8 \cdot$ II 各樹脂の耐薬品性の比較

\begin{tabular}{|c|c|c|c|c|c|c|c|c|c|}
\hline \multirow{3}{*}{\multicolumn{2}{|c|}{ 性 能 樹脂 }} & \multicolumn{6}{|c|}{ 不飽和ポエステル樹脂 } & \multicolumn{2}{|c|}{ ビニルエステル樹脂 } \\
\hline & & \multirow{2}{*}{ オルソ系 } & \multirow{2}{*}{ イソ系 } & \multirow{2}{*}{ TPA 系 } & ビ & 系 & \multirow{2}{*}{ ヘット酸系 } & \multirow{2}{*}{$\begin{array}{l}\text { ビスフェ } \\
\text { ノール形 }\end{array}$} & \multirow{2}{*}{ ノボラック形 } \\
\hline & & & & & $\mathrm{BPA}$ 系 & HBPA & & & \\
\hline \multicolumn{2}{|c|}{ 伸び率 \% (たわみ性) } & $(1.0 \sim 80)$ & $\begin{array}{c}2.0 \\
(1.0 \sim 80)\end{array}$ & 2.2 & 2.0 & 1.7 & 1.0 & 5.0 & 3.0 \\
\hline \multicolumn{2}{|c|}{ 熱ひずみ ${ }^{\circ} \mathrm{C}$ (酎熱性) } & (常温〜150) & (常温〜150) & 135 & 125 & 130 & 135 & 110 & 160 \\
\hline \multirow{4}{*}{$\begin{array}{l}\text { 耐 } \\
\text { 薬 } \\
\text { 品 } \\
\text { 性 }\end{array}$} & 耐 酸 性 & $\triangle$ & $\bigcirc$ & 0 & () & () & $\triangle \sim \bigcirc$ & () & () \\
\hline & 酎アルカリ性 & $x \times$ & $x \sim \triangle$ & $x$ & ()) & () & $\times$ & () & $\bigcirc$ \\
\hline & 酎 酸 化 性 & $x$ & $\triangle$ & $\triangle$ & $\bigcirc$ & $\bigcirc$ & () & $\bigcirc$ & $\bigcirc$ \\
\hline & 耐 溶 剂 性 & $\times$ & $\triangle$ & $\triangle$ & $x$ & $\triangle$ & $x$ & 0 & () \\
\hline
\end{tabular}

や公害防止装置（使用条件の変動が一般に激しい）の 構造材料として適して扔り, 最高 $150^{\circ} \mathrm{C}$, 常用最高 $100{ }^{\circ} \mathrm{C}$ 腐食性環境への使用が急速に伸びている.

\section{$8 \cdot 3 \cdot 3$ フェノール樹脂}

古くからある耐食樹脂で初めはフェノールとホルム アルデヒドの反応により造られたが，現在はユリアホ ルムアルデヒドおよびメラミンホルムアルデヒド樹脂 に発展している。良好な耐熱性（150 C まで）と耐酸 性を有するが，耐アルカリ性はよくない。

\section{$8 \cdot 3 \cdot 4$ フラン樹脂}

フラン樹脂は酸, アルカリの両方のみならず, 有機 溶剂にもよく耐える。とくに酸, アルカリに加えて有 機溶片が存在する場合によく耐えることで, 公害防止 装置の耐食材料として有用であると考光る。ただし， 強い酸化性の環境に対しては弱く，注意が必要である. また，フラン樹脂積層品は火災に対して発煙が少く， $260^{\circ} \mathrm{C}$ 高い熱変形温度を有する.

\section{$8 \cdot 4$ 耐食 FRP の耐食性}

表 8 ・II は耐食 FRP の各樹脂の耐薬品性の比較を 示す.

\section{$8 \cdot 5$ 有機ライニングによる腐食防止}

化学装置はじめ各種の機械装置の防食法のうち, ラ イニングあるいはコーティングなど有機材料の被覆に よる防食はもっとも手近に利用できる防食法である. 表 $8 \cdot$ III そ主な有機ライニングの概要を，また表 $8 \cdot N$ に主な有機コーティングの概要を示す.

\section{$8 \cdot 5 \cdot 1$ 熱硬化性樹脂ライニング}

最終重合を被施工物の表面で行わせるもので, 常温 硬化型（フラン，ポリェステル，エポキシーアミン， エポキシーポリアミド） と高温反応の焼付ニーティン グ型（フェノール，ェポキシーフェノール，エポキシー 尿素, シリコンなど）の 2 種がある. 
表 $8 \cdot$ III 有機ライニングの概要

\begin{tabular}{|c|c|c|c|c|c|c|c|}
\hline 材 料 名 & ポリ塩化ビニル & ポリエチレン & 四フッ化樹脂 & 三フッ化樹脂 & ニフッ化樹脂 & $\begin{array}{c}\text { 四・六フッ化樹脂 } \\
\text { (FEP) }\end{array}$ & 硬 質 ゴム \\
\hline 施 工 法 & 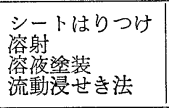 & $\begin{array}{l}\text { ディスパージョ } \\
\text { シ法 } \\
\text { 粉スプレー法 } \\
\text { 流彭漫せき法 }\end{array}$ & $\begin{array}{l}\text { ディスパージョ } \\
\text { ソ法 }\end{array}$ & $\begin{array}{l}\text { ディスパージョ } \\
\text { シ法 }\end{array}$ & $\begin{array}{l}\text { デイパージョン法 } \\
\text { 粉体スプレートインジ } \\
\text { シートランジ }\end{array}$ & $\begin{array}{l}\text { デイスパージョン } \\
\text { 法 }\end{array}$ & シート接着 \\
\hline 施 $\underset{\text { (燒付) }}{\text { 温 }}$ 度 & & $180 \sim 200^{\circ} \mathrm{C}$ & $350 \sim 380^{\circ} \mathrm{C}$ & $250 \sim 270^{\circ} \mathrm{C}$ & $250 \sim 270^{\circ} \mathrm{C}$ & $320 \sim 350^{\circ} \mathrm{C}$ & $\begin{array}{l}1 \sim 3 \mathrm{~kg} / \mathrm{cm}^{2} \\
\text { 飽和水蒸気で加硫 }\end{array}$ \\
\hline 最高使用温度 & 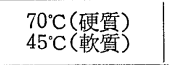 & $70^{\circ} \mathrm{C}$ & $250^{\circ} \mathrm{C}$ & $150^{\circ} \mathrm{C}$ & $130^{\circ} \mathrm{C}$ & $230^{\circ} \mathrm{C}$ & $100^{\circ} \mathrm{C}$ \\
\hline 耐 寒 温 度 & $-20^{\circ} \mathrm{C}$ & $-60^{\circ} \mathrm{C}$ & $-80^{\circ} \mathrm{C}$ & $-50^{\circ} \mathrm{C}$ & $-50^{\circ} \mathrm{C}$ & $-60^{\circ} \mathrm{C}$ & $-20^{\circ} \mathrm{C}$ \\
\hline $\begin{array}{c}\text { 標隼厚さ範团 } \\
(\mathrm{mm})\end{array}$ & $\begin{array}{l}2.5 \sim 5 \text { (硬覧) } \\
1.0 \sim 3 \text { (軟贔) }\end{array}$ & $1.5 \mathrm{~mm}$ 以上 & $00.2 \sim 0.1 \mathrm{~mm}$ & $0.3 \sim 0.4 \mathrm{~mm}$ & $0.5 \sim 1.0 \mathrm{~mm}$ & $0.05 \sim 0.2 \mathrm{~mm}$ & $3 \sim 6 \mathrm{~mm}$ \\
\hline $\begin{array}{l}\text { 一般的特性 } \\
\text { 用 途 }\end{array}$ & 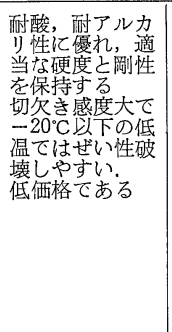 & 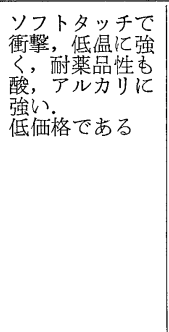 & 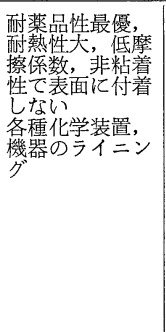 & 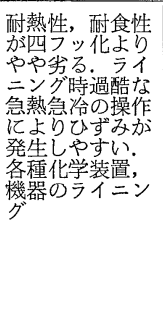 & 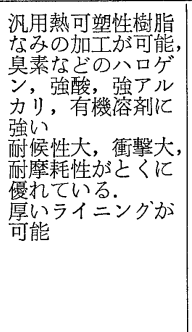 & 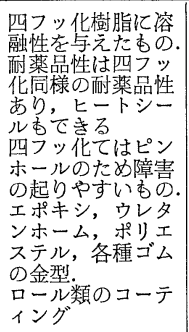 & 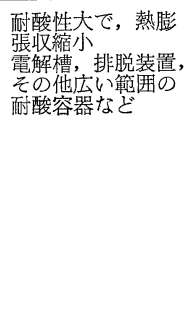 \\
\hline
\end{tabular}

\begin{tabular}{|c|c|c|c|c|c|c|c|c|}
\hline \multirow{2}{*}{ 材料 名 } & \multirow{2}{*}{ (軟臨ゴコムム) } & \multicolumn{4}{|c|}{ 合成コムライニング } & \multirow{2}{*}{ エポキシ樹脂 } & \multirow{2}{*}{ フラン 樹脂 } & \multirow{2}{*}{ 酎食ポリエステル } \\
\hline & & ネオプレン & プチル & ハイパロン & ニトリル & & & \\
\hline 施 工 法 & シート接着 & シート接着 & シート接着 & $\begin{array}{l}\text { シート接着 } \\
\text { 八ケ症 }\end{array}$ & シート接着 & $\begin{array}{l}\text { 隼涂装法 } \\
\text { 容射法 } \\
\text { FRP 法 }\end{array}$ & $\begin{array}{l}\text { 夜塗装法 } \\
\text { 容射法 } \\
\text { FRP 法 }\end{array}$ & $\begin{array}{l}\text { 留褻装法 } \\
\text { FRR 法 }\end{array}$ \\
\hline 施 $\frac{I}{\text { (烇付) }}$ 度 & 常 温 & 常 温 & 常 温 & 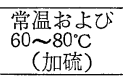 & 常 温 & 常缊または $150^{\circ} \mathrm{C}$ & $\begin{array}{c}\text { 種類によるる } \\
\left(\text { (常温または } 100^{\circ} \mathrm{C}\right)\end{array}$ & (種類まよる。 \\
\hline 最高使用温度 & $70^{\circ} \mathrm{C}$ & 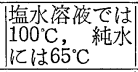 & $120^{\circ} \mathrm{C}$ & $100^{\circ} \mathrm{C}$ & $110^{\circ} \mathrm{C}$ & $\begin{array}{c}70^{\circ} \mathrm{C} \\
\text { (特殊 } 120^{\circ} \mathrm{C} \text { ) }\end{array}$ & $180^{\circ} \mathrm{C}$ & $100^{\circ} \mathrm{C}$ \\
\hline 耐寒 温度 & $-40^{\circ} \mathrm{C}$ & $-40^{\circ} \mathrm{C}$ & $-60^{\circ} \mathrm{C}$ & $-40^{\circ} \mathrm{C}$ & $-20^{\circ} \mathrm{C}$ & $-40^{\circ} \mathrm{C}$ & $-20^{\circ} \mathrm{C}$ & $-20^{\circ} \mathrm{C}$ \\
\hline $\begin{array}{c}\text { 標隼厚さ簙囲 } \\
(\mathrm{mm})\end{array}$ & $\begin{array}{l}3 \sim 5 \mathrm{~mm} \\
\text { (耐食用) } \\
5 \sim 25 \text { mm } \\
\text { (耐摩用) }\end{array}$ & & $\begin{array}{l}1 \sim 6 \mathrm{mn} \\
6 \sim 15 \mathrm{mn}\end{array}$ & $\begin{array}{l}\text { ר(耐食用) } \\
\text { (耐摩用) }\end{array}$ & & $\begin{array}{l}0.5 \sim 0.8 \mathrm{~mm} \\
1.0 \sim 5.0 \mathrm{~mm} \\
(\mathrm{FRP})\end{array}$ & $\begin{array}{l}0.5 \sim 1.0 \mathrm{~mm} \\
1.0 \sim 5.0 \mathrm{~mm} \\
(\mathrm{FRP})\end{array}$ & $\begin{array}{l}0.5 \sim 0.8 \mathrm{~mm} \\
1.0 \sim 50 \mathrm{~mm} \\
\quad(\text { FRP) }\end{array}$ \\
\hline $\begin{array}{l}\text { 一般的特性 } \\
\text { 用 途 }\end{array}$ & 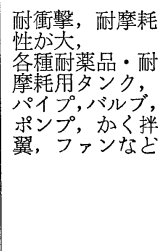 & 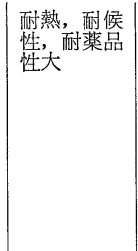 & 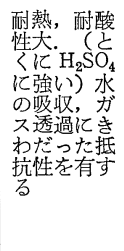 & 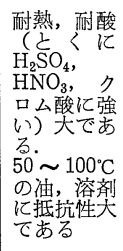 & 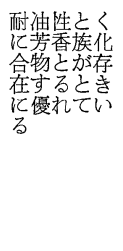 & 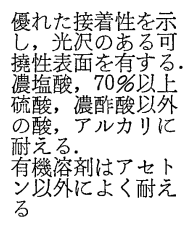 & 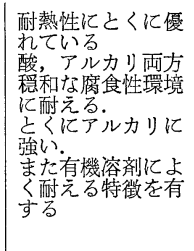 & 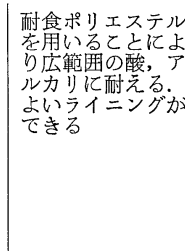 \\
\hline
\end{tabular}

(1) FRP ライニング 図 $8 \cdot 2$ に示すような耐 食構造の FRP をライニングするあのである.

（2）樹脂セメントライニング 熱硬化性樹脂をバ インダー（マトリックス）として適当に配合された骨 材を加えてモルタル状にしたもので, 耐酸床, 廃液ピ ットなどのコンクリートの防食用および耐食レンガの 目地材料として使用される.

（3）フレークライニング 厚さ $1 \sim 30 \mu \mathrm{m}$, 長さ $5 \mathrm{~mm}$ 以下の鱗片状のガラス粉末を樹脂に混入してぺ
ースト状にしたものをコテすたはスプレーガンによっ て 1〜3 mm の厚さにライニングしたもので, 薬液の 浸透を防ぐ効果が大きい.

\section{$8 \cdot 5 \cdot 2$ 熱可塑性樹脂ライニング}

樹脂を溶剤でとかした塗料タイプのほかに，粉末塗 装, ディスパージョン法, シートライニング法によっ てライニングする.

$$
8 \cdot 6 \text { 結言 }
$$

高分子材料を耐食部材として使いこなすことは防食 


\begin{tabular}{|c|c|c|c|c|c|c|c|c|c|c|}
\hline 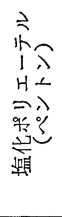 & 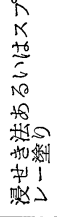 & $\begin{array}{l}0 \\
\text { o. } \\
\text { ?े } \\
\text { సิ }\end{array}$ & 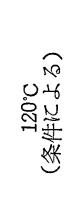 & 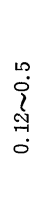 & 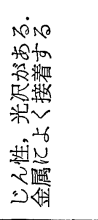 & 回 & 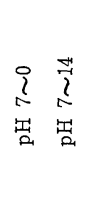 & $\begin{array}{l}\text { 安 } \\
\text { 政 }\end{array}$ & & 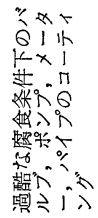 \\
\hline $\begin{array}{l}1 \\
a \\
\vdots \\
\vdots \\
z\end{array}$ & 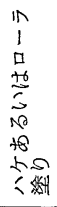 & $\begin{array}{l}\text { 咱 } \\
\text { 器 }\end{array}$ & \& & $\begin{array}{l}\text { m. } \\
0 \\
\text { i } \\
\text { जे } \\
\dot{0}\end{array}$ & 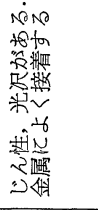 & $\begin{array}{l}\text { 出 } \\
\text { 正 }\end{array}$ & 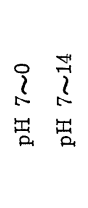 & 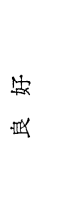 & & 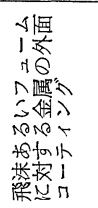 \\
\hline $\begin{array}{l}\hat{\lambda} \\
\vec{n} \\
t \\
k\end{array}$ & 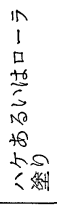 & $\begin{array}{l}\text { 㵋 } \\
\text { 䣈 }\end{array}$ & 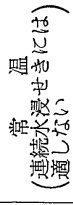 & $\begin{array}{l}20 \\
0 \\
? \\
\text { oे } \\
0\end{array}$ & 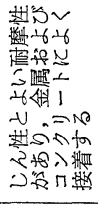 & 此 & 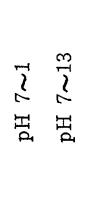 & $\begin{array}{l}\text { 出 } \\
\text { 西 }\end{array}$ & & 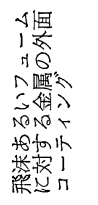 \\
\hline 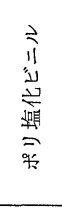 & 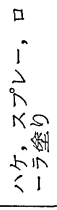 & 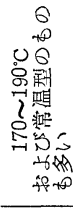 & 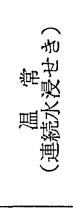 & $\begin{array}{l}\text { L } \\
i \\
\text { iे } \\
\text { İ } \\
0\end{array}$ & 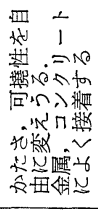 & 正 & 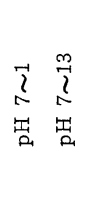 & $\begin{array}{l}\text { 回 } \\
k\end{array}$ & & 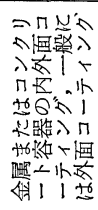 \\
\hline 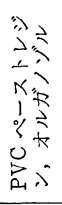 & 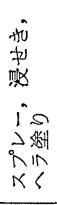 & $\begin{array}{l}0 \\
\dot{0} \\
\stackrel{2}{2} \\
? \\
\text { ? }\end{array}$ & 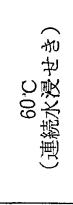 & 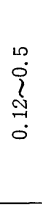 & 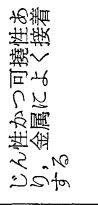 & $\begin{array}{l}\text { 出 } \\
\text { 霆 }\end{array}$ & 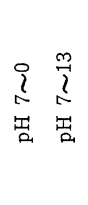 & $\begin{array}{l}\text { 回 } \\
k\end{array}$ & & 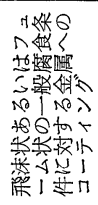 \\
\hline $\begin{array}{l}\lambda \\
\hat{x} \\
\Delta \\
\Delta \\
\hat{a} \\
\text { क्र }\end{array}$ & 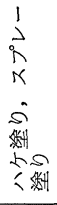 & $\begin{array}{l}\text { 勋 } \\
\text { 捛 }\end{array}$ & 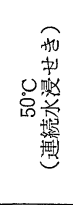 & $\begin{array}{l}\text { m. } \\
i \\
\text { iे } \\
0 \\
0\end{array}$ & 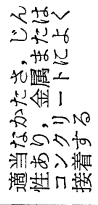 & 慗 & 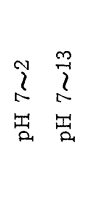 & $\begin{array}{l}\text { 㱑 } \\
\text { 踏 }\end{array}$ & 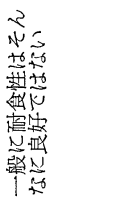 & 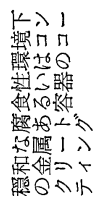 \\
\hline 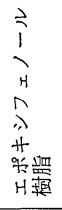 & 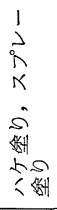 & $\begin{array}{l}0 \\
\stackrel{0}{0} \\
\text { Oे } \\
\text { l } \\
\text { \&్․ }\end{array}$ & 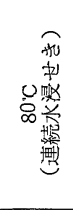 & $\begin{array}{l}\text { n } \\
i \\
i \\
\text { oे } \\
\stackrel{0}{0} \\
0\end{array}$ & 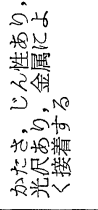 & 龊 & 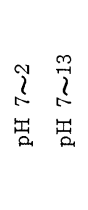 & $\begin{array}{l}\text { 岪 } \\
\text { 西 }\end{array}$ & & 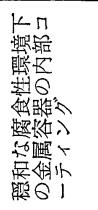 \\
\hline 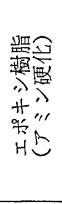 & 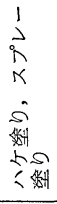 & 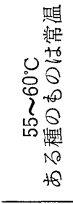 & 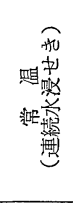 & 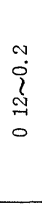 & 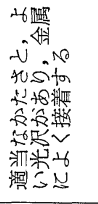 & 㹵 & 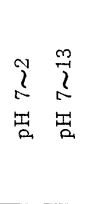 & 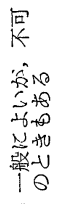 & 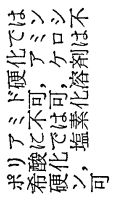 & 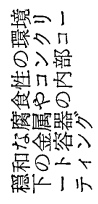 \\
\hline 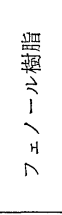 & 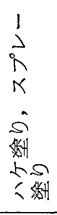 & 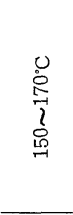 & 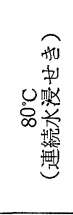 & 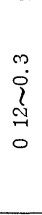 & 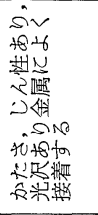 & 回 & 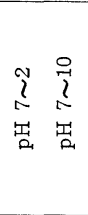 & $\begin{array}{l}\text { 嵓 } \\
\text { 正 }\end{array}$ & 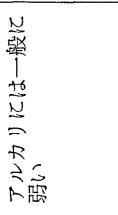 & 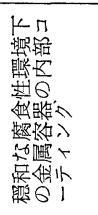 \\
\hline 卖 & 获 & 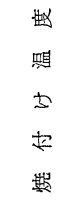 & 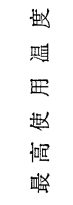 & 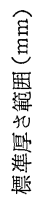 & 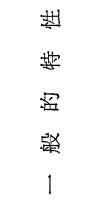 & 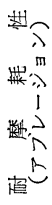 & 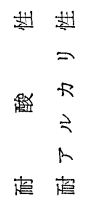 & 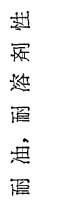 & $\begin{array}{l}1 \\
1 \\
4 \\
4 \\
4\end{array}$ & $\begin{array}{l}\text { 飽 } \\
\text { 田 } \\
+6 \\
+\infty\end{array}$ \\
\hline
\end{tabular}




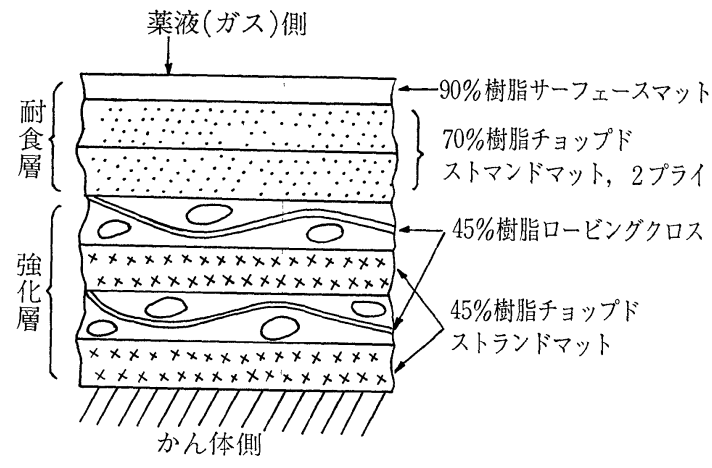

図 $8 \cdot 2$ 耐食構造の一例 (FRP ライニング)

設計上有用な手段である.使用条件に応じて最適な材 料を選定すること，それぞれの樹脂の特長と適用限界 を熟知して和くこと，適当な耐食性評価のための試験 法を採用し，使用条件に対する耐食性の評価を確実に
行うことが是非とも必要である。

\section{参考文 献}

1) 奥田 聡, “プラスチックスエージ・エンサイクロペデ イア 1971”, p. 213 (1970)，(株) プラスチックェージ

2) Toelcke, C.A., and A.B. Robertson, Modern Plastics, 50, 12, 74 (1973).

3）奥田 聡, プラスチックスエージ，2，97 (1977).

4）加藤晴久, プラスチックマテリアル，17，9，37 (1976). その他の一般的参考文献

1）奥田 聡, “内外に拈ける耐食プラスチック和よび耐薬 品性研究の動向”，プラスチックスエージ， 23, 1 12 (1977)；24, 1〜4 (1978).

2) 奥田 聡, “耐食 FRP の現状と問題点”，材料， 23, 902 (1974).

3）奥田 聡, “各種ライニングによる防食対策”, プラント エンジニア, p. 87 (1977). 